\title{
ПОРІВНЯЛЬНА ХАРАКТЕРИСТИКА РЕЗУЛЬТАТІВ ВИКОРИСТАННЯ АДЕМЕТІОНІНУ І ЙОГО ВІДДАЛЕНИХ ЕФЕКТІВ НА ПОКАЗНИКИ КЛІТИННОГО ІМУНІТЕТУ У СПОРТСМЕНІВ ВИСОКОЇ ПРОФЕСІЙНОЇ МАЙСТЕРНОСТІ І У ХВОРИХ НА ХРОНІЧНИЙ ГЕПАТИТ С
}

\author{
ДВНЗ «Тернопільський державний медичний університет імені І. Я. Горбачевського МОз України»
}

РЕЗЮМЕ. У спортсменів високої професійної майстерності на висоті максимальних фізичних навантажень спостерігаються статистично достовірні зміни з боку клітинного імунітету, які багато в чому нагадують аналогічні зміни при хронічному гепатиті С. Прийом спортсменами адеметіоніну у відновний період приводив до нормалізації показників клітинного імунітету, які залишалися стабільними у віддалений період.

Мета дослідження - провести порівняльний аналіз субпопуляцій лімфоцитів у спортсменів високої професійної майстерності в період максимальних фізичних навантажень і у хворих на хронічний гепатит С і визначити вплив гепатопротектора адеметіоніну на показники клітинного імунітетту в обох групах.

Матеріал і методи. Було обстежено 38 практично здорових осіб, 34 спортсмени-біатлоністи високої професійної майстерності на висоті максимальних фізичних навантажень і 40 хворих на хронічний гепатит С. Оцінювали показники клітинного імунітету: Т-лімфоцити (CD3+, CD19-), Т-хелпери/Т-індуктори (CD4+, CD8-), Т-супресори/Т-цитотоксичні клітини (CD4-, CD8+), імунорегуляторний індекс, цитотоксичні клітини (CD3+, CD56+), NK-клітини (CD3-, CD56+), В-лімфоцити (CD3-, CD19+), моноцити (CD14), загальний лейкоцитарний антиген (3ЛА, CD45). Методи діагностики: проточна цитофлуориметрія.

Результати. Визначені показники клітинного імунітету, які змінюються у спортсменів високої професійної майстерності в період максимальних фізичних навантажень; показаний позитивний вплив адеметіоніну на нормалізацію імунного статусу спортсменів під час його прийому і у віддалений період. При хронічному гепатиті С під час прийому адеметіоніну також спостерігали нормалізацію показників клітинного імунітету, але вона була нетривалою і зникала після відміни гепатопротектора.

Висновки. Адеметіонін позитивно впливає на показники клітинного імунітету як у спортсменів високої професійної майстерності в період максимальних фізичних навантажень, так і у хворих на хронічний гепатит С, але в останніх нормалізація була нетривалою.

КлючОВІ СЛОВА: фізичні навантаження; клітинний імунітет; спортсмени; гепатит С.

Вступ. Підвищена напруженість тренувального і змагального процесів у спорті вищих досягнень чинить на організм спортсмена екстремальну психофізичну дію, яка може бути причиною виникнення серйозних порушень діяльності низки органів і систем [2, 3]. До числа найчутливіших до граничних спортивних навантажень належить єдина регуляторна система організму, яка об'єднує разом нервову, ендокринну та імунну системи $[8,9]$.

Під впливом високих психофізичних навантажень показники системи імунітету можуть виходити за межі фізіологічних границь і мати патологічний характер, будучи причиною зростання захворюваності і зниження спортивної результативності $[5,7]$.

У зв'язку з цим не викликає сумніву необхідність контролю за змінами імунологічних показників спортсменів. Як показали численні дослідження $[1,4,6]$, контроль за станом імунної системи у спортсменів в процесі тренувальної і змагальної діяльності - об'єктивний і чутливий метод оцінки стану резистентності організму і міри адаптації його до спортивних навантажень.
Метою дослідження було вивчити показники клітинної ланки імунітету у спортсменів високої професійної майстерності на висоті максимальних фізичних навантажень у перший день після змагального періоду, вплив на них, в період відновлення, адеметіоніну і порівняти з аналогічними показниками при хронічному гепатиті С.

Матеріал і методи дослідження. 3 дотриманням принципів біоетики та деонтології на базі фізкультурного диспансеру було обстежено 38 практично здорових осіб, 34 спортсмени-біатлоністи високої професійної майстерності і 40 хворих на хронічний гепатит С. Було отримано інформовану згоду в письмовому вигляді. Матеріал для досліджень: венозна кров. Методи діагностики: проточна цитофлуориметрія.

Результати й обговорення. Наші дослідження показали, що кількість Т-лімфоцитів (CD3+, CD19-) статистично достовірно знижується (табл. 1), як у спортсменів високої кваліфікації, так і в хворих на хронічний гепатит С (відповідно на 13,2 \% і 13,3 \%), порівняно з контрольною групою. Статистично достовірної різниці між показниками спортсменів під час фізичних навантажень і хворих на 
Огляди літератури, оригінальні дослідження, погляд на проблему, ювілеї

хронічний гепатит С немає. Рівень Т-хелперів/ Т-індукторів (CD4+, CD8-) статистично достовірно також знижується і у спортсменів під час максимальних фізичних навантажень, і в хворих на хронічний гепатит С (відповідно на 31,7 \% і 27,4 \%), в порівнянні з нормою. Статистично достовірної різниці між показниками спортсменів під час фізичних навантажень і хворих на хронічний гепатит С немає.

Таблиця 1. Порівняльна характеристика оцінки субпопуляцій лімфоцитів у спортсменів

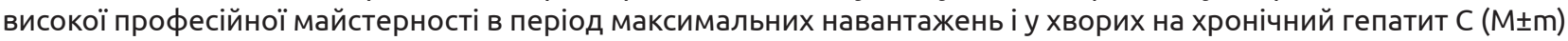

\begin{tabular}{|l|c|c|c|c|}
\hline \multicolumn{1}{|c|}{ Показники } & $\begin{array}{c}\text { Контрольна } \\
\text { група, } \\
\mathrm{n=38}\end{array}$ & $\begin{array}{c}\text { Спортсмени на } \\
\text { висоті максимальних } \\
\text { фізичних } \\
\text { навантажень, } \mathrm{n=34}\end{array}$ & $\begin{array}{c}\text { Хворі на } \\
\text { хронічний } \\
\text { гепатит С, } \\
\mathrm{n}=40\end{array}$ & \multicolumn{1}{c|}{$\mathrm{P}$} \\
\hline Т-лімфоцити (CD3+, CD19-) & $59,29 \pm 1,22$ & $51,41 \pm 1,49$ & $51,35 \pm 1,32$ & $>0,05$ \\
\hline Т-хелпери/Т-індуктори (CD4+, CD8-) & $35,95 \pm 1,39$ & $24,55 \pm 0,81$ & $26,09 \pm 0,65$ & $>0,05$ \\
\hline Т-супресори/Т-цитотоксичні клітини (CD4-, CD8+) & $23,45 \pm 0,48$ & $22,46 \pm 0,73$ & $13,95 \pm 0,72$ & $<0,05$ \\
\hline Імунорегуляторний індекс (CD4+, CD8-/CD4-, CD8+) & $1,55 \pm 0,06$ & $1,14 \pm 0,05$ & $2,25 \pm 0,27$ & $<0,05$ \\
\hline Цитотоксичні клітини (CD3+, CD56+) & $4,04 \pm 0,22$ & $2,8 \pm 0,14$ & $3,35 \pm 0,07$ & $<0,05$ \\
\hline NК-клітини (CD3-, CD56+) & $8,96 \pm 0,77$ & $4,78 \pm 0,2$ & $4,61 \pm 0,18$ & $>0,05$ \\
\hline В-лімфоцити (CD3-, СD19+) & $8,37 \pm 0,48$ & $6,21 \pm 0,3$ & $8,14 \pm 0,28$ & $<0,05$ \\
\hline Моноцити (СD14) & $7,11 \pm 0,21$ & $6,59 \pm 0,2$ & $6,58 \pm 0,19$ & $>0,05$ \\
\hline Загальний лейкоцитарний антиген (3ЛА, CD45) & $97,46 \pm 0,35$ & $91,56 \pm 1$ & $88,09 \pm 1,1$ & $<0,05$ \\
\hline
\end{tabular}

Кількість Т-супресорів/Т-цитотоксичних клітин (CD4-, CD8+) у спортсменів високої професійної майстерності в період максимальних фізичних навантажень практично не змінюється, а от у хворих з хронічним гепатитом С статистично достовірно зменшується, як в порівнянні з контрольною групою, так і з групою спортсменів високого класу (на 40,5 \% і 37,9 \% відповідно).

Імунорегуляторний індекс (CD4+, CD8-/CD4-, CD8+) статистично достовірно зменшується у спортсменів високої кваліфікації, порівняно 3 контрольною групою (на 26,4 \%), а от у хворих на хронічний гепатит С він статистично достовірно збільшується, порівняно з контрольною групою (на 45,1 \%). Між показниками імунорегуляторного індексу в спортсменів і хворих на хронічний гепатит C $\epsilon$ статистично достовірна різниця (у хворих на гепатит С цей показник практично $\epsilon$ удвічі вищим, ніж у спортсменів високої кваліфікації).

Кількість цитотоксичних клітин (CD3+, CD56+) статистично достовірно зменшується у спортсменів високої професійної майстерності в період максимальних фізичних навантажень, порівняно з контрольною групою (на $30,7 \%$ ). У хворих на хронічний гепатит С кількість даних клітин також статистично достовірно зменшується, порівняно з контролем (на 17,1\%). Між показниками кількості цитотоксичних клітин спортсменів і хворих на хронічний гепатит С існує статистично достовірна різниця (у хворих на хронічний гепатит С їх на 19,6\% більше).

Кількість NK-клітин (CD3-, CD56+) статистично достовірно зменшується у спортсменів високої майстерності на висоті максимальних фізичних навантажень та в хворих на хронічний гепатит С, порівняно $з$ контрольною групою (на 46,6 \% і
48,5 \% відповідно). Між показниками кількості NK-клітин (CD3-, CD56+) спортсменів і хворих на хронічний гепатит $C$ немає статистично достовірної різниці.

Кількість В-лімфоцитів (CD3-, CD19+) статистично достовірно зменшується у спортсменів високої майстерності в період максимальних фізичних навантажень, порівняно з контрольною групою (на 25,8 \%). Між показниками кількості В-лімфоцитів (CD3-, CD19+) спортсменів високої майстерності і хворих на хронічний гепатит С існує статистично достовірна різниця (у хворих на хронічний гепатит С ̈іх на 23,1 \% більше). Кількість В-лімфоцитів (CD3-, CD19+) у хворих на хронічний гепатит С статистично достовірно не відрізняється від їх кількості в контрольній групі.

Кількість моноцитів (CD14) статистично достовірно зменшується у спортсменів високої майстерності на висоті максимальних фізичних навантажень та в хворих на хронічний гепатит С, порівняно з контрольною групою (на 7,3 \% і 7,4 \% відповідно). Між показниками кількості моноцитів (CD14) спортсменів високої кваліфікації і хворих на хронічний гепатит $C$ немає статистично достовірної різниці.

Загальний лейкоцитарний антиген (ЗЛА, CD45) статистично достовірно зменшується у спортсменів високої майстерності в період максимальних фізичних навантажень та в хворих на хронічний гепатит С, порівняно з контрольною групою (на 6,1 \% і 9,6 \% відповідно). Між показниками загального лейкоцитарного антигена (ЗЛА, CD45) спортсменів високої кваліфікації і хворих на хронічний гепатит С статистично достовірної різниці немає. 
Огляди літератури, оригінальні дослідження, погляд на проблему, ювілеї

Порівняльний аналіз субпопуляцій лімфоцитів у хворих на хронічний гепатит С і у спортсменів високої професійної майстерності в період максимальних фізичних навантажень показав, що в обох випадках Т-лімфоцити (CD3+, CD19-), Т-хелпери/Т-індуктори (CD4+, CD8-), цитотоксичні клітини (CD3+, CD56+), NK-клітини (CD3-, CD56+), моноцити (CD14) і загальний лейкоцитарний антиген (ЗЛА, CD45) змінюються статистично достовірно односпрямовано, в бік зменшення. Відмінності $\epsilon$ лише щодо кількості Т-супресорів/ Т-цитотоксичних клітин (CD4-, CD8+), які у хворих на хронічний гепатит С статистично достовірно знижуються, а у спортсменів під час фізичних навантажень не змінюються, імунорегуляторного індексу (CD4+,CD8-/ CD4-, CD8+), який у спортсменів високої кваліфікації під час максимальних фізичних навантажень статистично достовірно знижується, а у хворих на хронічний гепатит С статистично достовірно підвищується. Крім того, існує відмінність щодо кіль- кості В-лімфоцитів (CD3-, CD19+) - у спортсменів під час максимальних фізичних навантажень цей показник статистично достовірно знижується, а у хворих на хронічний гепатит С практично не змінюєТься.

У період відновлення спортсменів високої кваліфікації, котрі приймали адеметіонін, змінювалися такі показники субпопуляцій лімфоцитів (табл. 2): кількість Т-лімфоцитів (CD3+, CD19-) статистично достовірно нижча на $15,8 \%$, кількість Т-хелперів/Т-індукторів (CD4+, CD8-) також статистично достовірно нижча на $15,8 \%$, кількість NK-клітин (CD3-, CD56+) статистично достовірно менша на $86 \%$, рівень В-лімфоцитів (CD3-, CD19+) статистично достовірно нижчий на 46,8 \% і концентрація моноцитів (CD14) статистично достовірно менша на 56,7 \%, порівняно з показниками субпопуляцій лімфоцитів у хворих на хронічний гепатит $C$, які, очікуючи на противірусну терапію, також приймали адеметіонін.

Таблиця 2. Порівняльна характеристика результатів використання адеметіоніну і його віддалених ефектів на показники субпопуляцій лімфоцитів у спортсменів високої професійної майстерності

і у хворих на хронічний гепатит C $(\mathrm{M} \pm \mathrm{m})$

\begin{tabular}{|c|c|c|c|c|c|c|c|c|}
\hline \multirow{3}{*}{ Показники } & \multirow[b]{2}{*}{$\begin{array}{c}\text { Конт- } \\
\text { рольна } \\
\text { група, } \\
\text { n=38 }\end{array}$} & \multicolumn{2}{|c|}{ Спортсмени } & \multicolumn{2}{|c|}{ Гепатит C } & \multirow{3}{*}{ p 2-3 } & \multirow{3}{*}{ p 4-5 } & \multirow{3}{*}{ p 3-5 } \\
\hline & & $\begin{array}{c}\text { через } \\
\text { місяць } \\
\text { прийому } \\
\text { адеметіо } \\
\text { ніну, n=18 }\end{array}$ & \begin{tabular}{|c|} 
через \\
10 днів після \\
припинення \\
прийому \\
адеметіо \\
ніну, $\mathrm{n}=10$ \\
\end{tabular} & $\begin{array}{c}\text { через } \\
\text { місяць } \\
\text { прийому } \\
\text { адеметіо } \\
\text { ніну, } \mathrm{n}=18\end{array}$ & $\begin{array}{c}\text { через } 10 \text { днів } \\
\text { після припи } \\
\text { нення } \\
\text { прийому } \\
\text { адеметіоніну, } \\
\text { n=10 }\end{array}$ & & & \\
\hline & 1 & 2 & 3 & 4 & 5 & & & \\
\hline $\begin{array}{l}\text { Т-лімфоцити } \\
\text { (CD3+, CD19-) }\end{array}$ & $59,29 \pm 1,22$ & $55,02 \pm 1,88^{*}$ & $66,25 \pm 2,26$ & $63,7 \pm 1,38$ & $61,51 \pm 4,8$ & $<0,05$ & $>0,05$ & $>0,05$ \\
\hline $\begin{array}{l}\text { Т-хелпери/ } \\
\text { Т-індуктори } \\
\text { (CD4+, CD8-) } \\
\end{array}$ & $35,95 \pm 1,39$ & $34,76 \pm 1,55^{*}$ & $47,31 \pm 1,57$ & $40,25 \pm 1,85$ & $29,14 \pm 2,98$ & $<0,05$ & $<0,05$ & $<0,05$ \\
\hline $\begin{array}{l}\text { T-супресори/ } \\
\text { Т-цитотоксичні } \\
\text { клітини (CD4-, CD8+) }\end{array}$ & $23,45 \pm 0,48$ & $26,32 \pm 0,86$ & $21,91 \pm 0,5$ & $26,92 \pm 0,99$ & $26,13 \pm 0,67$ & $<0,05$ & $>0,05$ & $<0,05$ \\
\hline $\begin{array}{l}\text { Імунорегуляторний } \\
\text { індекс (CD4 +,CD8-/ } \\
\text { CD4-, CD8 +) }\end{array}$ & $1,55 \pm 0,06$ & $1,33 \pm 0,05$ & $2,17 \pm 0,09$ & $1,55 \pm 0,11$ & $1,12 \pm 0,12$ & $<0,05$ & $>0,05$ & $<0,05$ \\
\hline $\begin{array}{l}\text { Цитотоксичні клітини } \\
\text { (CD3+, CD56+) }\end{array}$ & $4,04 \pm 0,22$ & $3,17 \pm 0,14^{*}$ & $5,23 \pm 0,24$ & $5,1 \pm 0,25$ & $5,1 \pm 0,38$ & $<0,05$ & $>0,05$ & $>0,05$ \\
\hline $\begin{array}{l}\text { NK-клітини } \\
\text { (CD3-, CD56+) }\end{array}$ & $8,96 \pm 0,77$ & $5,16 \pm 0,22 *$ & $8,04 \pm 0,45$ & $9,6 \pm 0,51$ & $7,38 \pm 0,61$ & $<0,05$ & $>0,05$ & $>0,05$ \\
\hline $\begin{array}{l}\text { В-лімфоцити } \\
\text { (CD3-, CD19+) }\end{array}$ & $8,37 \pm 0,48$ & $6,19 \pm 0,38 *$ & $8,2 \pm 0,78$ & $9,09 \pm 0,52$ & $8,22 \pm 0,28$ & $<0,05$ & $>0,05$ & $>0,05$ \\
\hline Моноцити (CD14) & $7,11 \pm 0,21$ & $6,4 \pm 0,2^{*}$ & $8,09 \pm 0,43$ & $10,03 \pm 0,37$ & $9,14 \pm 0,55$ & $<0,05$ & $>0,05$ & $>0,05$ \\
\hline $\begin{array}{l}\text { Загальний } \\
\text { лейкоцитарний } \\
\text { антиген (ЗЛА, CD45) }\end{array}$ & $97,46 \pm 0,35$ & $95,41 \pm 0,83$ & $97,2 \pm 0,35$ & $95,75 \pm 0,78$ & $96,47 \pm 0,54$ & $>0,05$ & $>0,05$ & $>0,05$ \\
\hline
\end{tabular}

Віддалені результати (через десять днів після закінчення прийому адеметіоніну) показників субпопуляцій лімфоцитів у спортсменів вищої професійної майстерності наступні: кількість Т-лім- фоцитів (CD3+, CD19-) статистично достовірно вища на 20,4 \%, кількість Т-хелперів/Т-індукторів (CD4+, CD8-) статистично достовірно більша на 36,1 \%, кількість Т-супресорів/Т-цитотоксичних 
Огляди літератури, оригінальні дослідження, погляд на проблему, ювілеї

клітин (CD4-, CD8+) статистично достовірно менша на $16,7 \%$, імунорегуляторний індекс (CD4+, CD8-/CD4-, CD8+) статистично достовірно вищий на $63,2 \%$, рівень цитотоксичних клітин (CD3+, CD56+) статистично достовірно більший на 64,9\%, концентрація NK-клітин (CD3-, CD56+) статистично достовірно вища на 55,8 \%, рівень В-лімфоцитів (CD3-, CD19+) статистично достовірно більший на $32,5 \%$, а кількість моноцитів (CD14) статистично достовірно більша на 26,4 \%, порівняно з показниками субпопуляцій лімфоцитів у спортсменів після місячного періоду відновлення з прийомом адеметіоніну. Щодо загального лейкоцитарного антигена (ЗЛА, CD45), то він статистично достовірно не змінювався, порівняно з показником загального лейкоцитарного антигену (ЗЛА, CD45) у спортсменів після місячного періоду відновлення з прийомом адеметіоніну.

Віддалені результати показників субпопуляцій лімфоцитів у хворих на хронічний гепатит С через десять днів після завершення місячного прийому адеметіоніну статистично достовірно не змінювалися, крім рівня Т-хелперів/Т-індукторів (CD4+, CD8-), який статистично достовірно був нижчим на 27,6 \%, порівняно з показниками в період очікування противірусної терапії хворими на хронічний гепатит С, котрі приймали адеметіонін.

Порівняльна характеристика результатів використання адеметіоніну і його віддалених ефектів на показники субпопуляцій лімфоцитів у спортсменів високої професійної майстерності та хворих на хронічний гепатит С показує, що кількість Т-хелперів/Т-індукторів (CD4+, CD8-) статистично достовірно більша у спортсменів високої майстерності на 38,4 \%, кількість Т-супресорів/ Т-цитотоксичних клітин (CD4-, CD8+) статистично достовірно менша на 19,3 \%, а імунорегуляторний індекс (CD4+, CD8-/CD4-, CD8+) статистично достовірно вищий на 48,4 \%, порівняно з показниками субпопуляцій лімфоцитів у хворих на хронічний гепатит C, які пройшли місячний період очікування на противірусну терапію з прийомом адеметіоніну.

Такі показники субпопуляцій лімфоцитів, як Т-лімфоцити (CD3+, CD19-), Т-хелпери/Т-індуктори (CD4+, CD8-), цитотоксичні клітини (CD3+, CD56+), NK-клітини (CD3-, CD56+), В-лімфоцити (CD3-,
CD19+), моноцити (CD14) у хворих на хронічний гепатит С значно краще реагували на прийом адеметіоніну протягом місяця у відновний період, порівняно з групою спортсменів, які також приймали адеметіонін: усі вищеперераховані показники у них були статистично достовірно вищими. 3 іншого боку, віддалені результати таких показників, як Т-хелпери/Т-індуктори (CD4+, CD8-) та імунорегуляторний індекс (CD4+,CD8-/CD4-, CD8+) у групі спортсменів, які приймали адеметіонін, виявилися статистично достовірно вищими, ніж у хворих на хронічний гепатит С. Т-супресори/ Т-цитотоксичні клітини (CD4-, CD8+) навпаки були статистично достовірно вищими у хворих на хронічний гепатит С. Та все ж, виходячи з того, що у спортсменів, які приймали адеметіонін, через десять днів після припинення його прийому фагоцитарний індекс виявився удвічі вищим, ніж в аналогічної групи хворих на хронічний гепатит С, ми вважаємо, що у спортсменів прийом адеметіоніну викликає більш стійкі тенденції відновлення субпопуляцій лімфоцитів.

Висновки. 1. В обох групах спортсменів високої майстерності, які період відновлення проходили без прийому адеметіоніну і які приймали адеметіонін, спостерігалося відновлення субпопуляцій лімфоцитів. Але в групі спортсменів вищої професійної майстерності, які приймали адеметіонін, такі показники як Т-хелпери/Т-індуктори (CD4+, CD8-), Т-супресори/Т-цитотоксичні клітини (CD4-, CD8+) і загальний лейкоцитарний антиген (ЗЛА, CD45) були статистично достовірно вищими, порівняно з групою спортсменів, які адеметіонін не приймали.

2. Прийом адеметіоніну хворими на хронічний гепатит С мав статистично достовірний позитивний вплив практично на всі показники субпопуляцій лімфоцитів, крім Т-супресорів/ Т-цитотоксичних клітин (CD4-, CD8+). Особливу увагу потрібно звернути на те, що більше, ніж в два рази зростає кількість NK-клітин (CD3-, CD56+) та практично нормалізується загальний лейкоцитарний антиген (ЗЛА, CD45). Але після відміни адеметіоніну у хворих на хронічний гепатит С спостерігалося погіршення показників клітинного імунітету.

\section{ЛІТЕРАТУРА}

1. Аронов Г. Е. Иммунологическая реактивность при различных режимах физических нагрузок / Г. Е. Аронов, Н. И. Иванова. - К. : Здоровье, 1987. - 86 с.

2. Макарова Г. А. Спортивная медицина : учебник / Г. А. Макарова. - М. : Советский спорт, 2004. - 480 с.

3. Спортивная медицина. Практические рекомендации : пер. с англ. / под ред. Р. Джексона. - К. : Олимпийская литература, 2003. - 383 с.
4. Суздальницкий Р. С. Иммунологические аспекты спортивной деятельности человека / Р. С. Суздальницкий, В. А. Левандо // Теория и практика физической культуры. - 1998. - № 10. - С. 43-46.

5. Суздальницкий Р. С. Новые подходы к пониманию спортивных стрессорных иммунодефицитов / Р. С. Суздальницкий, В. А. Левандо // Теория и практика физической культуры. - 2003. - № 1. - С. 18-22. 
Огляди літератури, оригінальні дослідження, погляд на проблему, ювілеї

6. Суркина И. Д. Роль иммунной системы в процессах адаптации у спортсменов / И. Д. Суркина, Е. П. Готовцева // Теория и практика физической культуры. 1991. - № 8. - С. 27-37.

7. Футорный С. М. Иммунологическая реактивность спортсменок как одно из направлений современной спортивной медицины / С. М. Футорный // Тео-

рия и практика физической культуры. - 2004. - № 1. С. 16-19.

8. Besedovsky H. O. Psychoneuroimmunology / H. O. Besedovsky. - New-York. - 1992. - 208 p.

9. Schwarz-Ottersbach E. Psychoimmunologie / E. Schwarz-Ottersbach // Schweiz. Rundseh. Med. Prax. 1989. - Vol. 13. - P. 362-366.

\title{
REFERENCES
}

1. Aronov, G.E., \& Ivanova, N.I. (1987). Immunologicheskaya reaktivnost pri razlichnykh rezhimakh fizicheskikh nagruzok [Immunological reactivity in various modes of physical activity]. Kiev: Zdorovye [in Russian].

2. Makarova, G.A. (2004). Sportivnaya meditsina: uchebnik [Sports medicine: textbook]. Moscow : Sovetskiy sport, p. 480 [in Russian].

3. Jackson, R. (Ed.). (2003). Sportivnaya meditsina. Prakticheskiye rekomendatsii [Sports medicine. Practical recommendations]. (Transl. from English). Kiev: Olimpiyskaya literatura [in Russian].

4. Suzdalnitsky, R.S., \& Levando, V.A. (1998). Immunologicheskiye aspekty sportivnoy deyatelnosti cheloveka [Immunological aspects of human sports activity]. Teoriya $i$ praktika fizicheskoy kultury - Theory and Practice of Physical Culture, 10, 43-46 [in Russian].

5. Suzdalnitskyy, R.S., \& Levando, V.A. (2003). Novyye podkhody k ponimaniyu sportivnykh stressornykh immuno-

defitsitov [New approaches to understanding sports stress immunodeficiency]. Teoriya i praktika fizicheskoy kultury Theory and Practice of Physical Culture, 1, 18-22 [in Russian].

6. Surkina, I.D., \& Gotovtseva, I.D. (1991). Rol immunnoy sistemy v protsessakh adaptatsii u sportsmenov [The role of the immune system in the processes of adaptation in athletes]. Teoriya i praktika fizicheskoy kultury - Theory and Practice of Physical Culture, 8, 27-37 [in Russian].

7. Futornyy, S.M. (2004). Immunologicheskaya reaktivnost sportsmenok kak odno iz napravleniy sovremennoy sportivnoy meditsiny [Immunological reactivity of athletes as one of the directions of modern sports medicine]. Teoriya i praktika fizicheskoy kultury - Theory and Practice of Physical Culture, 1, 16-19 [in Russian].

8. Besedovsky, H.O. (1992). Psychoneuroimmunology. New-York.

9. Schwarz-Ottersbach, E. (1989). Psychoimmunologie. Schweiz. Rundseh. Med. Prax., 13, 362-366.

\section{СРАВНИТЕЛЬНАЯ ХАРАКТЕРИСТИКА РЕЗУЛЬТАТОВ ИСПОЛЬЗОВАНИЯ АДЕМЕТИОНИНА И ЕГО ОТДАЛЕННЫХ ЭФФЕКТОВ НА ПОКАЗАТЕЛИ КЛЕТОЧНОГО ИММУНИТЕТА У СПОРТСМЕНОВ ВЫСОКОГО ПРОФЕССИОНАЛЬНОГО МАСТЕРСТВА И У БОЛЬНЫХ ХРОНИЧЕСКИМ ГЕПАТИТОМ С}

๑В. В. Грушко

\author{
ГВУз «Тернопольский государственный медицинский университет имени И. Я. Горбачевского \\ МОЗ Украины»
}

РЕЗЮМЕ. У спортсменов высокого профессионального мастерства на высоте максимальных физических нагрузок наблюдаются статистически достоверные изменения со стороны клеточного иммунитета, которые во многом напоминают аналогичные изменения при хроническом гепатите С. Прием спортсменами адеметионина в восстановительный период приводил к нормализации показателей клеточного иммунитета, которые оставались стабильными в отдаленный период.

Цель исследования - провести сравнительный анализ субпопуляций лимфоцитов у спортсменов высокого профессионального мастерства в период максимальных физических нагрузок и у больных хроническим гепатитом и влияние гепатопротектора адеметионина на показатели клеточного имунитета в обеих группах.

Материал и методы. Было обследовано 38 практически здоровых лиц, 34 спортсмена-биатлониста высокого профессионального мастерства на высоте максимальных физических нагрузок и 40 больных хроническим гепатитом С.

Оценивались показатели клеточного иммунитета: Т-лимфоциты (CD3+, CD19-), Т-хелперы / Т-индукторы (CD4+, CD8-), Т-супрессоры/Т-цитотоксические клетки (CD4-, CD8+), иммунорегуляторный индекс, цитотоксические клетки (CD3+, CD56+), NK-клетки (CD3-, CD56+), В-лимфоциты (CD3-, CD19+), моноциты (CD14), общий лейкоцитарный антиген (ОЛА, CD45). Методы диагностики: проточная цитофлуориметрия.

Результаты. Определены показатели клеточного иммунитета, которые меняются у спортсменов высокого профессионального мастерства в период максимальных физических нагрузок, показано положительное влияние адеметионина на нормализацию иммунного статуса спортсменов во время его приема и в отдаленный период. При хроническом гепатите С тоже во время приема адеметионина наблюдалась нормализация показателей клеточного иммунитета, но она была непродолжительной и исчезала после отмены гепатопротектора.

Выводы. Адеметионин положительно влияет на показатели клеточного иммунитета как у спортсменов высокого профессионального мастерства в период максимальных физическихнагрузок, таки у больныххроническим гепатитом С, но у последних нормализация была непродолжительной.

КЛючЕВЫЕ СЛОВА: физические загрузки; клеточный иммунитет; спортсмены; гепатит С. 


\section{COMPARATIVE CHARACTERISTICS OF THE RESULTS OF USING ADEMETIONINE AND ITS REMOTE EFFECTS ON CELLULAR IMMUNITY PARAMETERS IN HIGHLY SKILLED ATHLETES AND IN PATIENTS WITH CHRONIC HEPATITIS C}

๑V. V. Hrushko

\section{Horbachevsky Ternopil State Medical University}

SUMMARY. Athletes of high professional skill at the height of maximum physical activity observed statistically significant changes in cellular immunity, which in many respects resemble similar changes in chronic hepatitis $\mathrm{C}$. Admission of ademetionine by athletes during the recovery period led to normalization of cellular immunity indicators, which remained stable in the long-term period.

The aim of the study - to conduct a comparative analysis of lymphocyte subpopulations in athletes of high professional skills during the period of maximum physical exertion and in patients with chronic hepatitis and the effect of ademetionin hepatoprotector on the cellular immunity indices in both groups.

Materials and Methods. 38 practically healthy individuals, 34 athletes-biathlete of high professional skills at the height of maximum physical exertion and 40 patients with chronic hepatitis $C$ were examined. The cellular immunity parameters were evaluated: T-lymphocytes (CD3+, CD19-), T-helper / T-inducers (CD4+, CD8-), T-suppressors / T-cytotoxic cells (CD4-, CD8+), immunoregulatory index, cytotoxic cells (CD3+, CD56+), NK cells (CD3-, CD56+), B-lymphocytes (CD3-, CD19+), monocytes (CD14), common leukocyte antigen (OLA, CD45). Diagnostic methods: flow cytofluorimetry.

Results and Discussion. The indicators of cellular immunity, which vary in athletes of high professional skill during the period of maximum physical exertion, are determined, and the positive effect of ademetionine on the normalization of athletes' immune status during its administration and in the long-term period is shown. In chronic hepatitis $C$, normalization of cellular immunity parameters was also observed while taking ademetionine, but it was short and disappeared after the withdrawal of the hepatoprotector.

Conclusons. Ademethionine has a positive effect on cellular immunity, both in athletes of high professional skill during the period of maximum physical exertion and in patients with chronic hepatitis $\mathrm{C}$, but in the latter normalization was short-lived.

KEY WORDS: physical activity; cellular immunity; athletes; hepatitis C. 